\title{
Oor die Estetika van Kos en die Kookkuns ${ }^{1}$
}

\section{Ernst Wolff}

\author{
Departement Filosofie, \\ Universiteit van Pretoria, Pretoria, 0002 \\ ernst.wolff@up.ac.za
}

\begin{abstract}
On the aesthetics of food and the art of cooking
The aesthetic nature of food and cooking is a neglected field in philosophical aesthetics. This neglect is due, among others, to the intellectual perspective on art and the anthropological dualism characteristic of modernism. In this essay the aesthetics of food and the art of cooking are explored. The system of food in philosophy firstly examined. In the second part, a distinction is made between natural and culinary gastronomical beauty. Attention is given to the development of some philosophical terminology applicable to the field of study, and the art of cooking analysed in contrast to other forms of artistic expression. In the last section, some cultural and political implications of the aesthetics of food and the art of cooking are considered.

In die wêreld van die antieke Griekse filosowe was dit, soos by ons, die gebruik om simposia te hou. Hulle het egter daarvan gehou om van die filosofiese gesprek 'n feestelike geleentheid te maak: eers was daar 'n maaltyd en daarna is gefilosofeer en wyn gedrink. Deurentyd was daar musikante, mimiekkunstenaars, dansers en ander kunsmense om die denkers te vermaak of te stimuleer. Ons een van die gaste die ander begin verveel, is die party opgekikker deur die sondebok kaal om die tafel te laat dans of met wyn en afval van die ete te besmeer ${ }^{2}$. Dit mag dalk vir ons tydgenote ietwat onfatsoenlik lyk, want van hierdie feestelike integrasie van filosofie en kuns, denke en lewe het in ons tyd nie veel oorgebly nie. Die estetika van kos het veral swaar hieronder gely.
\end{abstract}

Kos as die onderwerp van kuns is niks ongewoon nie ${ }^{3}$. Daarenteen is kos as onderwerp van die Westerse filosofiese estetika nieqxqgewilde onderwerp nie ${ }^{4}$. Dit is moeilik om hierdie verskynsel te verklaar, veral in die lig van die feit dat alle filosowe in die geskiedenis hulle met kos bemoei het in hulle alledaagse lewe. Ek stel my dit in hierdie artikel ten doel om 'n perspektief op die estetika van kos aan te bied: ' $n$ bydrae

1 Hierdie artikel is gebaseer op navorsing wat oorspronklik in 1997 onderneem is.

2 Sien Kroll \& Mittelhaus (1932).

3 Dit geld vir al die genres van kuns, met legio voorbeelde: van Van Gogh se Aartappeleters tot Bach se Kaffee-Kantate; in die filmwêreld dink mens maklik aan Babette's Feast, Like Water for Chocolate of Big Night; dink ook aan die groente-tema in Breytenbach se Gebed van ' $n$ fasistiese pampoen, of Brink se vertelling van hoe hy 'n pampoen deur die strate van Parys gedra het in Latynse reise.

4 Vername uitsonderings is die bekende werk van Anthelme Brillat-Savarin (1755-1826), La physiologie $d u$ goût (1826) en twee belangrike onlangse werke, Elizabeth Telfer se Food for thought (1996) en Carolyn Korsmeyer se Making sense of taste (1999). 
sal gemaak word tot ons begrip van die waardering van skoonheid in kos en van die eiesoortigheid van die kookkuns (met ander woorde van dit wat die blote biologiese funksionaliteit daarvan oorskry), asook van die intellektuele, kulturele en politieke milieu waarin die skoonheid van kos en die kookkuns tot betekenis kom. Dit spreek vanself dat ek binne die perke van een artikel nie 'n Summa Gastronomica kan uitwerk nie; die relatief geringe aandag wat nog aan hierdie onderwerp bestee is, regverdig egter 'n verkennende studie waarin 'n ander oriëntasie ontwikkel kan word. Ek bepaal my by drie sake wat 'n billike perspektief op die estetika van kos en die kookkuns behoort voor te stel, en gelyktydig aan sekere enkelaangeleenthede aandag te gee, maar sonder om daarmee op volledigheid aanspraak te maak. Eerstens word 'n interpretasie van die plek van kos in die filosofie gegee. In die tweede deel word die estetiese aard van kos en die kookkuns beskryf, deur hierdie onderwerpe in verband te bring met sommige van die terme en probleme wat algemeen gebruik word in die filosofiese estetika. Ten slotte word gekyk na die groter filosofiese belang van kos, ten einde 'n beeld te vorm van die implikasies van wat ookal in 'n estetika van kos uitgewerk word en om hierdie estetika te situeer ten opsigte van ander navorsing wat oor kos gedoen is in filosofie en wat daarop ' $\mathrm{n}$ invloed kan hê. Kuns en die estetiese bestaan immers nie in isolasie van die res van die werklikheid nie.

\section{Kos en filosofie}

\subsection{Lewe, oorlewing, goed lewe}

Alle mense eet. Alle mense wat nie eet nie, is dooie mense. Selfs wanneer iemand opqxqeetstaking gaan, is die lewe sonder kos reeds moontlik gemaak deurdat daar vroeër geëet is. Eet is 'n moontlikheidsvoorwaarde vir die mens se biologiese voortbestaan. As integrale deel van die mens se bestaan as biologiese organisme, hou eet direk verband met die basiese drang om oorlewing. Edo ergo sum - ek eet daarom is ek. Daar is ander dinge wat die mens ook doen om aan die lewe te bly, byvoorbeeld asemhaal. Maar anders as met asemhaal, toon die wyse waarop mense eet dat eet nie net daaroor gaan om die lewe te kontinueer of om te oorleef nie, maar om op 'n spesifieke manier te leef. Die adverbialiteit wat eet bydra tot my sum is toe te skryf aan die verbeelding en die sosiale vorming van eet. Dit is die estetiese aspek van voeding. Wanneer ons eet, word ons moeite om te oorleef, oorskry en bemiddel deur ons begeerte om goed te leef. Om goed te leef deur te eet beteken om in te gryp in die omgewing en om deel te neem aan die sosiale praktyke en betekenisnetwerk waarin ons geworpe is. ${ }^{5}$ Kortom, om te eet is een van die mees basiese maniere waarop die mens estetiserend aan sy/haar wêreld deelneem en sodoende sy/haar eie lewe estetiseer. Die genoemde aspekte van die mens se omgang met kos sal deur die opstel verder uitgewerk word.

5 Sien Versfeld (1982:111): "Ons leef in wisselwerking met die natuur en met ander mense, en een van die belangrikste maniere waarop ons dit doen, is deur te eet. Daar sit groot waarheid in Feuerbach se diktum: Der Mensch ist was er isst, veral wanneer ons daaroor nadink dat ons die omgewing nie net met ons tande nie, maar ook met gees en sinne eet. Dat ons die landskap met ons tande vorm, uitbeitel, kan ons maklik agterkom deur bo-op Pêrelberg te gaan sit. Die ploegbare grond is alles aan die produksie van kos oorgegee. Daar is groot wingerde, groot boorde, groot saailande. Daar is talle plaaswonings en volkshuisies, paaie vir die vervoer van produkte, groot fabrieke waar die produkte verwerk word tot wyn, blikkieskos, ens." "Eet" en "kos" is sleutelterme sowel in Versfeld se estetika as in sy filosofie van die tegniek en bind, tewens, die twee dele van sy werk saam. 


\subsection{Lyflikheid en estetika}

Die mens wat is, die mens wat eet, is lyflik. In pas met Descartes se dualisme, is daar in die moderne Westerse filosofieqxqspesifieke posisie aan die lyf toegeken. Hiervolgens was daarqxqneiging om 'n radikale skeiding te maak tussen die denkende subjek en die materiële werklikheid waartoe die lyf behoort. ${ }^{6}$ Die woonplek van die waarheid sou in die interne ruimte van die indiwiduele mens se denke wees en die eksterne wêreld moes daardeur oorheers word.

Ten spyte van die mate waarin hierdie dualisme al filosofies ondermyn is, leef dit steeds in sekere praktyke in die kunswêreld voort. Mens sien dit byvoorbeeld in die algemeen aanvaarde gedrag van toeskouers by klassieke musiekopvoerings, waar dit betaamlik is om die lyf stil te hou en eers na afloop van die opvoering opqxqgekontroleerde en fatsoenlike manier jou byval deur applous bekend te maak. Die subordinasie van die lyf word soms nog by kunstenaars aangetref.qxqEkstreme voorbeeld hiervan vind ons by sekere lyfkunstenaars of "body artists". Chris Burden hetqxqkunswerk tot stand gebring deur homself te laat skiet; Gina Pane (sic!) het patrone op haar lyf metqxqskeermeslem gekerf (sien Atkins, 1990:54-56). Uiteraard gaan dit nie hier daaroor om die geldigheid of moontlikhede van "body art" as sodanig te ontken nie, maar om te sien hoe die dualisme steeds kultureel neerslag vind (hoewel ek nie beweer dat dit die leidende tendens in kuns is nie) en die mens toelaat om sy/haar lyf as 'n medium te behandel.

As dit die geval is met kuns, dan nog soveel te meer met die estetika. Kant en Hegel se estetika is veelseggend in dié verband. In paragrawe $§ \S 51-53$ van die Kritik der Urteilskraft, vind ons verskillende kunste wat vir Kant deel uitmaak van die groep skone kunste. Binne hierdie groep word die onderskeie skone kunste hiërargies georden. Kant gee wel toe dat verskillende sulke hiërargieë opgestel sou kon word, telkens afhangend van die kriteria wat aangewend word, maar die indeling in $§ 51$ sou as verteenwoordigend van sy standpunt geneem kon word. Hier is die ordeningsbeginsel die vermoë van die onderskeie kunste om estetiese idees tot uitdrukking te bring. Spraakkunste is hier aan die top van die lys, gevolg deur die beeldende kunste en die kunste van klank en kleur. In $\$ 53$ word toonkuns voor beeldende kuns geplaas. Dit is duidelik dat hierdie hiërargie verband hou met die sintuie wat telkens by die waardering van elkeen van die kunswerke ter sprake kom. Daarom is die keerkant van die hiërargie van kunste,qxqhiërargie van sintuie. Sig en gehoor bied volgens Kant verreweg die belangrikste sintuiglike ervarings van die skone. Gevoel kom wel ter sprake in argitektuur, tuinbou en beeldhouwerk, maar inqxqondergeskikte rol. Na reuk word daar slegs inqxqanalogie verwys en van smaak is daar nie sprake nie. Die slotsom is dat die ondergeskikte sintuie nie 'n estetiese verhouding tot die werklikheid kan bemiddel of kan bydra tot die estetiese waardering van kunswerke nie. Om Kant se term te gebruik, dien ruik, voel en proe nie die ontwikkeling van estetiese "smaak" nie. Kookkuns kan

6 Net nadat Descartes in sy tweede meditasie die lyf asqxqorganiese meganisme beskryf het, lys hy 'n paar van die verskyningsvorme van hierdie masjien, waaronder die feit dat dit sigself voed: "Nempe occurrebat primo me habere vultum, manus, brachia, totamque hanc membrorum machinam, qualis etiam in cadavere cernitur, et quam corporis nomine designabam. Occurrebat praeterea me nutriri, incedere, sentire, et cogitare..." ("dit het in die eerste plek geblyk dat ekqxqgesig, hande, arms en hierdie geheel van lede van die meganisme, soos wat dit ook by 'n kadawer aangetref word, en wat ek met die naam 'lyf' benoem het. Voorts het dit geblyk dat ek myself voed, loop, voel en dink..." - my vertaling), aangehaal volgens Descartes (1641[1967]:183). 
nie vir Kant as skone kuns geld nie, nie net omdat dit 'n doelmatige praktyk is nie, maar weens die feit dat hy sekere sintuie beperk tot die domein van suiwer spel met gevoelens. Die rede vir hierdie dominansie van sig en gehoor wat ons by Kant aantref gaan waarskynlik so ver terug as die voorrang van sig en gehoor in die Westerse waarheidsbeskouing. Dit is onder andere toe te skryf aan die dominansie daarvan in twee voedingsbronne van die Westerse filosofie, naamlik die klassieke Griekse en Joodse denke. Oor die moontlike afsku van of vrees vir sintuiglike genot wat Kant se piëtistiese agtergrond aan hom sou leer, hoef ek nie nou te spekuleer nie.

Hegel is hieroor nog meer eksplisiet. In die Inleiding tot sy Lesings oor die Estetika beskryf hy die oorsprong van kuns as volg: "Das allgemeine und absolute Bedürfnis, aus dem die Kunst (nach ihrer formellen Seite) quillt, findet seinen Ursprung darin, daß der Mensch denkendes Bewußtsein ist, d.h. daß er, was er ist und was überhaubt ist, aus sich selbst für sich macht.'(1835[1970]:50-517) Dis duidelik dat sy idee van kuns bepaal word vanuitqxqsterk primaat van die rede en die bewussyn. Hoewel hy blykbaar aanvaar dat elkeen van die sintuie toegang tot estetiese ervarings het, word die kuns wat met die "laer" sintuie geassosieer is, uitdruklik uit kuns uitgesluit: "Deshalb bezieht sich das Sinnliche der Kunst nur auf die beiden theoretischen Sinne des Gesichts und Gehöhrs, während Geruch, Geschmack und Gefühl vom Kunstgenuß ausgeschlossen bleibt. Denn Geruch, Geschmack und Gefühl haben es mit dem Materiellen als solchem und den unmittelbar sinnlichen Qualitäten desselben zu tun. [...] Das für diese Sinne Angenehme ist nicht das Schöne der Kunst.'(1835[1970]:61 ${ }^{8}$ ). Dit blyk dus duidelik dat kookkuns vir Hegel geen kuns kan wees nie en dít, weereens, vanweë die noue verhouding tussen sy (Westerse) waarheidsbegrip en die primaat van die sintuie van gehoor en sig (let op Hegel se uitdrukking "theoretischen Sinne"). Die rede vir die uitstluiting uit die kunste van die drie mindere sintuie van estetiese ervaring berus op die feit dat hulle te doen het met die "Materielle als solche". Die cartesiaanse dualisme word hier in 'n gemetamorfiseerde vorm bevestig.

Dat die drie sintuie by uitnemendheid in die estetiese waardering van kos meer direk by die fisiese werklikheid aansluit, soos wat Hegel beweer, wil ek nie ontken nie. My betoog is egter dat ons nie dieselfde afkerende oordeel daaroor hoef te hê nie en dat ditqxqander perspektief op estetika oopmaak wat tot dusver nog nie die aandag gekry het wat dit verdien nie. Die nabyheid van die drie "eet-sintuie" aan die wêreld waarvan die mens afhanklik is (soos bo beskryf), hetqxqliggaamlike keerkant wat onderliggend aan die bewussyn en die rede is: die lokus van die mens se bewussyn as liggaam is ook die plek waar die inname van kos ervaar word. Die lyflike ervarings van voeding is mede-konstitutief van die bewussyn. Daarom is erns met die lyflikheid van die mens die uitgangspunt vir my estetika van kos. Hoewel die dualisme of die voorrang van die rede bo die lyf miskien vandag in die kuns en estetika agterhaal is, leef dit steeds voort in die ondergeskikte posisie wat die estetika van kos en die kookkuns beklee. Selfs as iemand alleen eet word daar kritiek uitgeoefen teen 'n oor-verheerliking van die posi-

7 'The universal and absolute need from which art [...] springs, has its origin in the fact that man is a thinking consciousness, i.e. that man draws out of himself and puts before himself what he is and whatever else is.' (1979:30-1).

8 'Consequently the sensuous aspect of art is related only to the two theoretical senses of sight and hearing, while smell, taste, and touch remain excluded from the enjoyment of art. For smell, taste, and touch have to do with matter as such and its immediately sensible qualities [...] What is agreeable for these senses is not the beauty of art.' (1979:38-9) 
sie van die subjek, omdat die afhanklikheid van die mens teenoor die natuur en die samelewing deur eet, bevestig word. Aan die ander kant word die intellektualisme in sekere uitdrukkingsvorme van kuns uitgedaag deur die onmoontlikheid daarvan om sekere ongeskrewe perke in die kookkuns te oorskry: hierdie perke word aan die kookkuns opgelê deur die feit dat dit verbind is met die sorg vir die self as lyf (sien die bespreking later oor avant-garde kookkuns). Maar hier loop ek die argument vooruit. Kom ons kyk nou na die skoonheid van kos.

\section{Die skoonheid van kos}

'n Paar pogings is al aangewend om perspektiewe op die estetika van kos of op aspekte daarvan voor te stel. Die werk van Telfer (1996) en van Korsmeyer (1999) byvoorbeeld debateer die vraag of die kookkuns as kunssoort beskou kan word en indien wel, tot watter mate. In hierdie afdeling lê ek die aksent anders, naamlik om te probeer omqxqbydrae te maak tot die interpretasie van die estetiese aard van kos en die kookkuns, sover die perke van die artikel dit toelaat. Hierdie taak sal gedoen word deurqxqhoeveelheid terme en probleme wat bekend is in die filosofiese estetika met die skoonheid van kos en die kookkuns in verband te bring en deur erns te maak met die betekenismatige bemiddelling van voeding as ' $n$ estetiese bemiddelling. Vir hierdie doeleindes, onderskei ek twee verskyningsvorme van kos. Aan die een kant is daar kos in die natuurlike, onverwerkte vorm, soos dit van die plant of dier kom. Aan die ander kant is kos as artefakte, waaronder ek die verwerking, vermenging, bak en brou van die onverwerkte bestanddele verstaan. Hierdie onderskeid stem ooreen met die ou onderskeid in estetika tussen die skoonheid van die natuur en die skoonheid van kuns, wat ek dus hier op die estetika van kos oordra.

Uit die bespreking sal dit duidelik word dat daar eintlik nie iets soos 'n blote voorwerp van voeding in die natuur bestaan nie, maar dat dit wat die mens in die natuur ter voeding vind, altyd reeds deur die mens se verstaan bemiddel is - hierdie bemiddeling is onder andere esteties van aard.

\subsection{Die gastronomiese skoonheid van die natuur}

Onderliggend aan enige beskouing van die skoonheid van die natuur is 'n algemene beskouing van die materiële wêreld. Ten einde hiermee in die reine te kom, vind ek aansluiting by Versfeld, juis omdat sy beskouing van die natuur direk verbind is met sy estetika van kos. Sy klein opstel, Cooking the marvellous ${ }^{9}$, dien as toegang tot die relevante perspektief wat hy in hierdie verband bydra.

In hierdie essay polemiseer Versfeld teen die funksionele natuurbeskouings van Sartre en teen wat wat hy noem "populêre Darwinisme". Hy haalqxqdeel uit Sartre se La Nausée aan waar die karakter Roquentin sy gewaarwordings vanqxqboom se wortel ad nauseam beskryf. Vir Roquentin is die probleem wat hom naar maak, dat daar 'n obsene oorbodigheid van detail aan die wortel se funksie toegevoeg is: "Sartre represents this godless universe as gooey and obscene, exuding a sort of nauseous plasma,"maar dit is juis waarin Versfeld soveel vreugde vind:

Things are superfluous: they overflow. They are so much more than a mere function. The root is a sheer function overlaid with disgusting superfluities. What a universe of sheer functions would be like is almost to horrific to imagine. One should notice the connection between function and generality. All

9 Die essay het verskyn in die bundel Food for Thought. A Philosopher's Cookbook (1991:89-93). 
roots as functions are the same, and what makes them particular is the overburden of disgusting extras. What is assassinated is the unique: this particular onion which I am peeling with delight. (1991a:90)

En verder op dieselfde bladsy sê Versfeld oor die spikkels op die orgidieë: "As for the orchids? Sheer fun and droll generosity - and pleasure in the unique. God did not, like Sartre, kotch over the orchids." By die populêre Darwinisme het Versfeld dit teen die oorheersende beginsel van nuttigheid:

This or that variation is useful. The splendour of the orchid, the quinine in the bark, are useful for survival. Hence the notion of nature red in tooth and claw. Each bit of life is one ego trying to get in ahead of the others. Capitalist nature! The result is a nature shorn of all superfluity and largesse which turns into egoism the glory of humility with which the thing, the substance, celebrates its own being. What is fundamental in reality is not self-preservation but generosity. (1991a:92)

Om saam te vat: Versfeld ontken nie die funksie van dinge in die natuur nie, maar verwerp die funksionalistiese reduksie. Op grond van hierdie beskouings, maak hy sekere gevolgtrekkings vir die samelewing. Hy beskou elke mens as oorbodig en dit is net as iemand dít besef, dat hy/sy nie meer ander mense of die natuur sal wil uitbuit nie. Op sy tipiese manier, met verwysing na Augustinus, sê Versfeld dan dat die mens uit die natuur kan leer wat die aard van liefde is - "love is creatively spontaneous" (1991a:92). Terwyl ek sy kritiek van die funksionalistiese reduksie en die nuttigheidsdogma oorneem, moet daar tog bepaalde voorbehoude oor Versfeld se natuur-beskouing geopper word, omdat dit relevant is vir die etiese implikasies van sy estetiese rehabilitasie van die natuur. Alhoewel hy nie in beginsel teen evolusie is nie, is dit tog vir hom gemaklik om in hierdie essay a-histories te werk te gaan. Hy vergeet te maklik dat die moord van een dier opqxqander (wat net in natuur-video's en toerisme-advertensies mooi is) nie 'n navolgenswaardige voorbeeld vir die menslike gemeenskap daar kan stel nie. Hierdie verband tussen natuur en etiek tersyde, is Versfeld se bydrae op die gebied van die skoonheid van die natuur en die perspektief wat dit vir ons open op die natuurlike skoonheid van kos, van groot belang; met hierdie perspektief in die agterkop, kan die gastronomiese skoonheid van die natuur beskryf word.

Neem die volgende voorbeeld as vertrekpunt. As ek naqxqappelkoosboom gaan om iets te ete te kry, sal ek nie aan die hand vanqxqdefinisie van watqxqappelkoos is voor die voet al die voorwerpe binne hierdie definisie val, pluk om hulle een vir een te verorber nie. Ek sal welqxqvooruitskatting maak van watter van daardie appelkose die lekkerste sal wees. Daardie oorbodige aspek van my interaksie met appelkose wat my genot gee, noem ek die gastronomiese skoonheid van die natuur. Dit het welqxqsubjektiewe referensie, omdat nie alle mense dieselfde smaak voorkeure deel nie. Fenomenologies toon dit die struktuur vanqxqontdekking. Die vermoë om vooruit te skat watter voorwerpe die meeste gastronomiese skoonheid gaan hê voordat hulle geproe is, noem ek verbeelding. ${ }^{10}$ Verbeelding antisipeer die kwaliteit en aard van 'n gastronomiese ervaring. Terwyl die verbeelding na die toekoms uitgestrek is, word dit egter ge-

10 Ek het nog op geen deeglike ontwikkeling van verbeelding in estetika van kos afgekom nie. Hoewel Brillat-Savarin (1826) in sy Meditasie 3, waarin "Die onderwerp van gastronomie" bespreek word, noem dat die studie van gastronomie die effek van voeding op onder andere die verbeelding van mense bestudeer, gee hy self geen aandag hieraan nie. In wat volg, kan die gastronomiese verbeelding net in 
ïnformeer en gevorm deur die geheue. Hierdie siening van verbeelding kan ook in ander terreine van die estetika toepassing vind en dit speel tewensqxqbelangrike rol in die mens se hantering van sy/haar lewe in die algemeen. Ten spyte daarvan dat die verbeelding kan fouteer, speel dit togqxqbelangrike heuristiese rol. Die verbeelding streef na vinding, en die deug wat ter bereiking hiervan gekultiveer moet word, is vindingrykheid. Dit wat uiteindelik deur die vinding van natuurlike skoonheid aan my gegee word oorskry die blote funksionering daarvan. Die natuurlike skoonheid van kos is nie net voeding nie; dis ookqxqgawe, 'n geskenk. Dit is die estetiese vrygewigheid wat die meganistiese perspektief op die werklikheid ophef. Daarom kan die vinding nooit tot die uitsluitlike vindingrykheid van die verbeeldingryke vinder gereduseer word nie.

\subsection{Die skoonheid van die kookkuns}

My vertrekpunt in hierdie paragraaf was die onderskeid tussen die onverwerkte kos wat net so genuttig word en die verwerkte vorme van kos wat die kookkuns aan ons voorsit. Die bespreking van die gastronomiese skoonheid van die natuur het ons egter daarop gewys dat daar nie iets soosqxqbrute voedingsobjek bestaan nie. Kos is altyd die objek van begeerte, van verbeelding, van waardering, van teleurstelling en dies meer. Kortom, die voorwerpe van voeding is net toeganklik deur bemiddeling van estetiese oordeel. In ons eietydse wêreld word hierdie bemiddeling versterk deur praktyke van voedseltegnologie: ons loop nie meer deur die natuur op soek na kos nie (jag isqxqstokperdjie, 'n tydverdryf), maar kry ons primêre voedselvorme van die plaas af. Die "onverwerkte" produk van die land af is reeds (en in sommige gevalle vir eeue al) die produk van tegnieke van bevordering van opbrengs, manipulering van genetiese samestelling, ensovoorts. Laasgenoemde is deur praktiese en ekonomiese oorwegings bepaal, maar ook deur gastronomiese voorkeure. Die plaas is by uitnemendheid die plek waar die ars (tegniek) en ars (kuns) met mekaar saamval.

Die estetiese kwaliteit van kos word verder gevoer deur gewilde of gepoogde intervensie (meng, sif, bak, ensovoorts) tot die diversifisering en bevordering van eet ervarings en hul estetiese kwaliteit - dit is die kookkuns. Die ars van die kookkuns, voeg by die verbeelding en vinding nou ook die aspek van uitvoering (of "performance"). Laasgenoemde is eweneens ' $n$ term wat tot altwee kante van ars behoort.

Om die aard van die kookkunswerk te verstaan, sal ek dit eerstens kontrasterend in verband bring met die idees van representasie en die sublieme, wat onderskeidelik met die moderne en die post-moderne estetika geassosieer word. Lyotard se L'inhumain (1991:108-118 \& 119-128 $\left.{ }^{11}\right)$ dien hierin as oriëntasie.

Die modernistiese toepassing van representasie en van 'n kommunikasiemodel op kuns kan nie sonder meer op die kookkuns toegepas word nie. Terwyl Telfer (1996:58) beweer dat respresentasie afwesig is van kos omdat dit niks vir ons oor onsself of oor die wêreld sê nie, lys Korsmeyer (1999:115-140)qxqhele verskeidenheid van tipes representasies wat deur kos gekommunikeer kan word ${ }^{12}$. Ek stel voor dat die vraag oor representasie of kommunikasie in kos met behulp van 'n onderskeid hanteer moet word: aan die een kant is daar die vraag of daar in kos of in die praktyk van voe-

breë trekke uitgewerk word; 'n vollediger ondersoek hiervan sal die onderwerp van 'n afsonderlike studie moet maak.

11 Verwysings is deurgans na die Engelse vertaling, The Inhuman.

12 Sy bespreek kos as simbole, voorbeeldskepping ('exemplification', dit is 'the symbolic relation in which 
ding en in die besonder in die estetiese aard daarvan iets gekommunikeer word (in wat volg betoog ek vir nee in 'n eerste sin, en ja in 'n tweede); aan die ander kant moet die onontkenbare wedersydse verwysing tussen kos en ander aspekte van die werklikheid en waar die estetiese aard nie voorop staan nie, aandag geniet (aspekte hiervan sal in $\S$ 3 aangeraak word).

Daar kan nie eenduidig sprake wees van representasie in cuisine nie. Die rede wat ek hiervoor aanvoer is dat die estetiese kwaliteit van die kookkunswerk onskeibaar verbind is aan die voedingsfunksie daarvan ${ }^{13}$. Vir sover ons ons bepaal by "blote" voeding is eetqxqdirekte partisipasie aan die werklikheid. Daar isqxqaspek van die mens as eter waarin hy/sy eenvoudig in uitruiling of wisselwerking met die omgewing is. Die fetus voed voordat hy/sy voorstellings voortbring. Hierdie verhouding van uitruiling met die omgewing, waarin ' $n$ mens nie veel anders as plankton of mikrobes is nie, verdwyn nooit, behalwe wanneer die dood intree. Vir solank voeding op hierdie vlak beskou word, kommunikeer die estetiese aspek van kos niks nie, al is die gastronomies-estetiese aspek van kos altyd hiervan afhanklik. Wat wel gebeur, is dat die mens se kapasiteit tot verbeelding en estetiese oordeel ontwikkel. Hierdie vermoë is egter altyd noodwendig sosiaal geïnvesteer: deur te verbeel en te beoordeel identifiseer ek myself soos my sosio-kulturele omgewing my gevorm het. Hierdie sosiale aspek is talig; dit kommunikeer (bewustelik of onbewustelik) waarde-oordele aan diegene wat ons omring. Sodoende word voor-oordele gesanksioneer, genormaliseer en oorgedra. In hierdie baie wye en indirekte sin van die woord, is daar dus "kommunikasie" in die gebruik van kos. Alles wat met die kookkuns geassosieer word; tegnieke van kultivering en voorbereiding, maniere van aansit, fatsoenlikheidsreëls, gebruike van uitnodiging en feeste, ensovoorts, maak deel uit van die habitus van die kookkuns. Daar is geen kookkuns sonder habitus nie. ${ }^{14}$

Maar die simboliese waarde van kos - polities, seremonieel, religieus of wat ookal is nie noodwendig afhanklik van die estetiese kwaliteit daarvan nie (sien Korsmeyer, 1999:143-4). Daarom behandel ek dit § 3, waar die breër sosio-politieke situasie van die estetika van kos en die kookkuns aan die orde kom. Hierdie situasie is egter nie sonder invloed op die estetiese waardering van die kookkuns nie, net soos die bestaan van 'n museum en die hele institusionele parafinalia wat daarvoor nodig is, die skildery wat daarin hang as mede kunswerk konstitueer.

Die aard van voeding het my genoop omqxqkomplekse antwoord te gee oor die modernistiese eis van kommunikasie in die kookkuns. Kan die kookkuns metqxqpost-modernistiese idee van die sublieme in verband gebring word? In aansluiting by Kant, beskryf Lyotard die sublieme as 'n ervaring waarvan die estetiese kwaliteit nie-kommunikeerbaar is, omdat die persoon wat dit ervaar eenvoudig daardeur oorweldig word (Sien Kant 1790[1991], §§23-29 en Lyotard 1991:109, 113, 125-126). In ons dag en tyd, sê Lyotard, poog avant-garde skilders om te antwoord op die vraag wat skilder is, deur sigself te situeer in die plek wat deurqxqestetika van die sublieme geopen is - dit beteken dat avant-garde (skilder)kuns nie antwoord op die vraag oor wat

an object both possesses a property and refers to it" [1999:128]), assosiasie of uitdrukking, seremonies en rituele.

13 Selfs die gebruik van kos vir nie-maaltyddoeleindes, bv. koekies, lekkers, biltong, koffie, ens. word deur medici met fisiese- of psigo-somatiese behoeftes in verband gebring.

14 Hierdie Bourdieusiaans geformuleerde argument stem breedweg ooreen met dié wat Korsmeyer (1999:129-130) met behulp van die werk van Mary Douglas maak. 
skilder is, deur uitmuntend te skilder nie, maar deur ondersoek in te stel na wat kuns enigsins moontlik maak (vgl. Lyotard 1991:125). In dié sin is avant-garde kuns filosofies. ${ }^{15}$ Avant-garde kuns kan dus nie steun opqxqgemeenskaplike smaak, op 'n sensus communis, nie, omdat dit die praktyk van kuns as sodanig problematiserend, en daarom ondermynend, ondersoek. Daarom dat hierdie kunswerke vormloos, monsteragtig of negatief voorkom (vgl. Lyotard, 1991:125).

Dit lyk onwaarskynlik datqxqavant-garde kookkuns in hierdie sin van die woord ooit werklik ontwikkel sal word. Ek stel my dit moeilik voor dat mense in beduidende hoeveelhede na die tafels van die mees vooraanstaande avant-garde kokke sal gaan (soos hulle na museums en konsertsale "vir eietydse kuns" gaan) ten einde daar in die gees van die sublieme gewalg te word. Anders as in die skilderkuns, is dit dus moeilik vir die kookkuns om in pas met die idee van die sublieme gepraktiseer te word. Hierdie oortuiging word gemotiveer deur die feit dat voeding onlosmaaklik deel is van die sorg vir die self as lyflik (waarna ek vroeër reeds verwys het). Dit beteken nie dat alle mense goed eet nie (hiervan is die massa-konsumpsie van gemorskos sprekend), maar mense sal hulle net in hoogs uitsonderlike omstandighede blootstel aan voeding wat vir hulle skadelik is. Maar miskien verdien die vermoede krediet dat sommige mense in bepaalde situasies oorval word metqxqbuitengewone verhouding tot kos waardeur soqxqpersoon gekonfronteer word met die angswekkende nabyheid aan die geweld van die wêreld en aan sy/haar eie verganklikheid. Dit kom miskien nader aan dít wat Kant die dinamiese sublieme van die natuur genoem het (Kritik der Urteilskraft, $\S \S 28-29)$. Dit gaan hier wel oorqxqverhouding (in 'n baie breë sin) tot kos wat verwerk is en in dié sin reeds onder estetiese vorming (onder ars) staan. Ek wil drie sulke moontlikhede noem:

1. In lyding onder die simptome van siektes wat met diëet te make het, byvoorbeeld anoreksie en bulimie.

2. Moontlik kan die sublieme in 'n mistiese of godsdienstige ervaring van kos ervaar word, byvoorbeeld in rites, waarvan sommiges bo en behalwe etes ook die gebruik van hallusinogene middels insluit.

3. By totale gebrek aan kos en waar so 'n gebrek aanleiding gee tot wat normaalweg as afwykende gedrag beskou word, byvoorbeeld antropofagie.

Uit hierdie voorbeelde blyk dit weereens duidelik dat die gebruik van kos (en daarom die oordenking van 'n estetika van kos) nie van die sosiale leefwêreld van mense geskei kan word nie.

Soms is dit nie eenvoudig om werke van die kookkuns te onderskei van ander kunsvorme nie. Die belang lê hier nie vir my om waterdigte skeidings in die domein van die kunste te bring nie, maar om die onderskeid te oorweeg ten dienste van 'n beter begrip van die kookkuns. Dink hier aan die voorbeeld van versiersuiker-versierings en ander soortgelyke skeppings, wat nie (of nie noodwendig) gemaak is om geëet te word nie. Troukoeke val dikwels in hierdie kategorie. Ons het hier te make metqxqestetiese baster. Hierdie skeppings is niks anders as beeldhouwerke met kos as medium nie. In hierdie werke vind 'n verplasing van genre plaas wat die gastronomies-estetiese beoordeling daarvan afskud, omdat dit nie as reuk, smaak of orale gevoel dien nie. Die ver-

15 Cf. Lyotard (1991:121): "Painting thus becomes a philosophical activity: the rules of formation of pictural images are not already stated and awaiting application. Rather, painting has as its rule to seek out these rules of formation of pictural images, as philosophy has as its rule to seek out the rules of philosophical sentences." 
plasing van kuns genre nooi ons uit om verder na te dink oor die verskil tussen die kookkuns en ander kunste.

Die spesifieke vorm van tydelike duursaamheid van die kookkuns kan vergelyk word met dié van ander kunsvorme. Kunsvorme soos skilder, beeldhou en argitektuur hetqxqbesondere tydlose kwaliteit in vergelyking met ander kunsvorme. Dit is dié eienskap wat veroorsaak dat ek kunswerke van honderde jare oud vandag nog kan waardeer en wat dit geskik maak om in museums of as nasionale gedenkwaardighede bewaar te word. Ander kunste soos dans, opera, toneel en musiek is nooit twee keer presies dieselfde nie, al berus die uitvoering op die interpretasie vanqxqteks, draaiboek of partituur wat gemeen is aan al die uitvoerings. Die kookkuns as uitvoering lê nader aan hierdie kunsvorme; die kookkunswerk kan dikwels beskou word asqxqinterpretasie vanqxqteks, die resep. Daarmee word nie die homogeniserende effek van massakultuur op die kookkuns misgekyk nie: een MacDonald's burger proe presies soos enige ander MacDonald's burger (wat terloops ook dieselfde proe as die houer waarin dit verpak word). Uitvindings soos die bandopnemer en die video kamera stel ons egter in staat omqxqaspek van die bogenoemde interpretatiewe kunsopvoerings feitlik tydloos te bewaar, al gaan daarqxqdeel van die ware aard van hierdie kunssoorte in die proses van opname verlore.qxqWare kookkunswerk is egter onherhaalbaar: nadat dit geëet is, kan die kos nooit weer geproe word nie; deur metabolisme word die kunswerk verteer; die disintegrasie en verbygaan van die kunswerk is die genot daaraan. Omdat daar geen opname en argivering van die meesterlike maaltyd moontlik is nie, is die kookkuns meer verbygaande as ander interpretatiewe kunsvorme. Daarby moet ook onthou word dat, terwyl die lede van die gehoor by 'n musiekopvoering dieselfde uitvoering op verskillende maniere beluister, die gaste aan dieselfde tafel nie heeltemal dieselfde ete eet nie - nie net omdat elkeen sy eie porsie eet nie, maar omdat elkeen sy eie eetspoed en sekwensie van elemente van die maaltyd vasstel.

Soos met ander kunssoorte, is daar by die kookkuns ook die "toeskouer" of die "gehoor" (in aanhalingstekens, nie om die sigbare en hoorbare aspekte van die kookkuns en die kookkuns-habitus te ontken nie, maar om die estetika-vooroordeel ten gunste van sig en gehoor in hierdie terme uit te lig. Hellen Keller kon ook die kookkuns geniet). Ons noem hulle lekkerbekke, lekkertande, gastronome, smulpape, vrate, gaste en dies meer. Die uitnemende waardeerder van die kookkuns is die connoisseur of fynproewer. Natuurlik is dit nie net mense wat eet nie. Die manier van kosgebruik by mense verskil in die eerste plek van dié van diere dat diere se verbeelding nie so goed ontwikkel is as mense s'n nie. Vergelyk byvoorbeeld die benadering tot vrugtebome by ape met dié van mense soos bó beskryf: die aap toon wel voorkeure met betrekking tot smaak, maar die vrugte van een boom word voor die voet uitprobeer, omdat die verbeelding nie die tekort aan sintuiglike detail so vindingryk kan aanvul as mense nie. Tweedens is daar nie by diere die nuttiging van kookkunswerke in die sin waarin ek dit by mense aan die orde gebring het nie. Tog sien ons dat, waarqxqvoëlpaar hulle kleintjies voed, daar sowel verwerking asqxqsosiale dimensie van kos is. Ek moet dus in my onderskeid oor die produsering en waardering van kos by mense en diere 'n onderskeid inbou oor die aard van ars by mense en diere. Hierdie probleem is soortgelyk aan dié wat Marx aanspreek in die Kapital (Boek V, 1872[1932]:179-180), waar hy vrae stel oor die verskil tussen die arbeid van mense en diere. Die perspektief wat hy voorstel is as volg: "Ons veronderstel arbeid as iets uitsluitlik mensliks.qxqSpinnekop verrig dade, wat soorgelyk is aan dié vanqxqwewer, en 'n by beskaam deur die bou 
van sy wasselle vele menslike bouersmeesters. Maar wat die slegste bouermeester uit die staanspoor beter maak as die beste by, is dat hy die sel in sy kop gebou het voor hy dit met was bou." ${ }^{16}$ Myns insiens is die verskil in die vermoë om kos voor te berei by mense teenoor diere die vernuf van die verbeelding (sien bespreking hierbo) en die vaardigheid van die ars wat gelyktydig estetiserend en sinstigtend is. ${ }^{17}$

Ek het reeds getoon dat eet 'n radikale dualistiese antropologie problematiseer. Die beskouing van die estetiese ervaring as geïnkarneerd het uiteraard betrekking op die waardering van die kookkuns. Die spreekwoord "honger is die beste kok" verwoord die algemene kennis dat die mens se fisiese toestand sy/haar waardering van kos beinvloed. Hierdie invloed van die liggaam op estetiese oordeel geld natuurlik vir ander kunssoorte ook. Aan die ander kant beïnvloed die mens se geestestoestand ook die manier wat daar met kos omgegaan word en hoe dit waardeer word, byvoorbeeld in die geval van dieetsiektes.

\section{Kos en kookkuns in die samelewing en politiek}

Estetika is ook gemoeid met die sosiale en/of politike implikasies van kuns: die kunswerk word byvoorbeeld beskou as draer vanqxqopvoedings- of sosiaal-kritiese taak, of die kunswerk fyn tendense in die samelewing registreer, en dies meer. Daar is meer aan kuns as net dit wat in privaatheid tussen die "toeskouer" en die kunswerk afspeel. Dit geld sekerlik ook vir die kookkuns. Die estetika van kos is nie net van estetiese belang nie. Ongeag van wat mens se beskouing oor die aard van gastronomiese skoonheid is, is dit nodig om die eetgebeure sosio-polities te kan situeer.qxqEstetika van kos en die kookkuns moet sigself dus afvra: wat is die tipe sosiale invloede waarmee rekening gehou moet word wedersyds tussen die estetiese gebeurtenis en die sosiale of politieke historiese konteks daarvan? Wat is die sosiale of politieke verwysings van die maaltyd en watter aspekte van hierdie konteks souqxqinvloed kon hê op die algemene verstaan en die konstituering van die objek van gastronomiese skoonheid? In hierdie paragraaf word nagedink oor enkele aspekte van hierdie situering, uiteraard sonder om die onderwerp hier te kan uitput. Dit bied ookqxqnatuurlike geleentheid om dit wat in hierdie artikel oor die estetika van kos gesê word, te situeer binne 'n groter raamwerk van filosofiese nadenke oor kos en voeding-verwante kwessies.

Moderne sosiale tendense blyk eerder hierdie situering van eet te weerspreek. Die opkoms van individualisme in die moderne tyd word weerspieël in Rousseau se beskrywing van die natuurlike mens as "dwalend deur die woude [...] sonder verbintenis, sonder enige behoefte aan ander mense en eweseer sonder enige begeerte om hulle te skaad, miskien sonder om enigeen van hulle ooit te ken [...]" (1990[1755]:96 $\left.{ }^{18}\right)$. Die oorspronklike mens se natuur is dus volgens Rousseau om ook alleen te eet. Hoewel dit die manier is waarop mense dikwels behandel word, bevestig die sosiologie en kul-

16 'Wir unterstellen die Arbeit in einer Form, worin sie dem Menschen ausschließlich angehört. Eine Spinne verrichtet Tätigkeiten, die denen des Webers ähneln, und eine Biene beschämt durch den Bau ihrer Wachszellen manchen menschlichen Baumeister. Was aber von vornherein den schelchtesten Baumeister vor der besten Biene auszeichnet, ist, daß er die Zelle in seinem Kopf gebaut hat, bevor er sie in Wachs baut.'.

17 Die onderskeid tussen mens en dier is egter myns insiens nie 'n wesensaak nie - die enigste rede waarom dit interessant kan wees om te dink oor die moontlikheid of nie daarvan om kookkuns by diere aan te tref is vir so ver dit 'n bydrae maak tot ons begrip van die kookkuns as sodanig.

18 'errant dans les forêts [...] sans liaison, sans nul besoin de ses semblables comme sans nul désir de leur nuire, peut-être même sans jamais en reconnaître aucun individuellement [...]' (my vertaling). 
tuurgeskiedenis dat die mens 'n sosiale eter is. Dat mense in groot getalle alleen eet, is eintlik 'n heel resente ontwikkeling in die mensdom se geskiedenis. Die wortel van die gemeenskaplike maaltyd kan gesoek word in die orale verhouding van kind tot moeder. Die borsvoeding van kindertjies is die basis van die maaltyd in familiale verband. Naas seksuele ervarings word dit beskou as die mees intieme fisiese verhouding tussen mense. $^{19}$

Daar is egter ookqxqandersoortige sosiale aspek van eet. Vir mense wat die moeilikheid van alleen jag en die afwesigheid van tegniek om groot hoeveelhede kos (soosqxqgejagde bok) te berg moes trotseer, het saam eet en kossoek groot voordele ingehou (vgl. Goody, 1982:154-174). Selfs vandag berus ons kosvoorsiening op dieselfde beginsels. Dink maar aan die groot sosiale netwerk wat benodig word omqxqbrood of vis in 'n woonstel in Johannesburg te kry. Hierdie sosiale netwerk bevestig die sosiale afhanklikheid van mense onderling en weerspieël die werksverdeling met al die sosio-politieke implikasies wat dit saamdra.

Die oorneem van resepte of elemente van die kookkultuur van een kultuurgroep deur ' $n$ ander, asook die verskillende elemente van wat ek die habitus van die kookkuns genoem het, dra verder daartoe by om die sosiale en historiese (tradisionele) terugbinding van die kookkuns te bevestig.

Messelken (1980:41-58) betoog dat saam eet nie net iets is wat mense doen as hulle saam honger is nie. Die mens neem nie net waar nie, maar probeer ook verstaan. Die lewe word nie net geleef nie maar ook beleef. Die mens word bewus van sy/haar eie verganklikheid - van die dood. Daarom begin die mens naqxqdieper rede vir bestaan soek. Die dreiging van die dood word ook hanteer deur kommunikasie met ander mense, omdat hulle dieselfde stryd stry. Só probeer mense om hulle tuiste/geborgenheid in die kosmos terug te vind. In hierdie solidariteit tussen mense begin die enkeling, vanweë sy/haar organiese selfstandigheid, skeiding van die groep te vrees. In hierdie situasie verenig godsdiens mense in 'n sisteem van simbole, en so word angs oorwin. Kos as simbole in rites is van die volopste simbole wat hierdie sinvolle konstituering van die verhouding kollektief/individu beliggaam.

In sy artikel oor hierdie onderwerp, verduidelik Greschat (1980:29-39) hoe die behoud van fisiese lewe en die vermyding van fisiese dood deur die inname van kos 'n uitgebreide, vergeestelikte parallel kry in die godsdiens. Hier kry kos die betekenis van behoud van geestelike lewe en die vermyding van geestelike dood (in "positiewe" godsdiens), en lewe en dood van magie of heksery (in "negatiewe" godsdiens).

Hierdie betekenis kry dan beslag in eet en drink, soos gereguleer deur velerlei taboe-reëls, reëls oor rituele eet en vas, ens. Hier word dus gepoog om nie net die funksie nie, maar ook die skoonheid van kos te transendeer tot 'n hoër betekenis of sindui-

19 Ongelukkig kan die interessante verband tussen eet en seks nie hier verder uitgewerk word nie. Psigoanaliste meen dat stimulasie tydens borsvoeding die eerste fase van libido-ontwikkeling verteenwoordig (sien byvoorbeeld Zauner, 1980:84-94). Verder word hierdie verband ook getrek in die godsdiens en in die besonder in die orgiastiese rituele in die sogenaamde 'negatiewe' godsdienste en magie (sien byvoorbeeld Ahmed, 1994:236-243). Die terme 'positiewe' en 'negatiewe' godsdienste wat later weer ter sprake sal kom, word ontleen aan Ahmed, wat dit as ordende eerder as beoordelende kategorieë beskryf. Eersgenoemde verteenwoordig die hoofstrome in die groot wêreldgodsdienste, terwyl laasgenoemde godsdienstige praktyke dek wat dikwels ondergronds en in opposisie tot eersgenoemde beoefen word, soos swart magie, heksery, nekromansie, alchemie en okkultisme. Vir die doeleindes van hierdie studie is Ahmed se onderskeid bloot van belang om die wyd uiteenlopende en selfs direk weerspekende betekenisse van kos in religie uit te wys. 
ding. Die rol van kos in godsdiens het verder te doen met groepsaffiliasie (dit is gebaseer op die identiteitstigtende funksie wat kos in enige samelewing het). Waar die kos in 'positiewe' godsdiens ten dienste van 'n bepaalde heilsdoel staan, word dit in 'negatiewe' godsdiens gebruik om sake buite die deelnemer met egoïstiese bedoelings te probeer manipuleer. ${ }^{20}$

Dit behoort ons dan nie te verbaas dat ons juis in die domein van die godsdiensqxqetiese en sosiale uitwerk van die betekenis van kos en etes sal vind nie. Die bekendste voorbeeld hiervan is die godsdienstig-politiese program van die historiese Jesus. In die sterk hiërargies geordende wêreld waarin hy opgetree het, is invloed op alle terreine uitgeoefen deur verhoudings van beskermheer en begunsdigte (patron-client relations) en die familie was die sterkste sosiale instelling. Hierdie situasie, saam met die godsdienstige sanksionering van onderdrukkende praktyke, het gesorg virqxqmassa arm, ontwortelde, familielose kleinboere en die sogenaamde afskryfbares (expendables). Jesus bied aan hierdie mense 'n godsdienstig-sosiale herdefiniëring van die familie, wat in die praktyk bevestig word deur medelye in gemeenskaplike etes (sien Van Staden, 1991). Hierdie sosiale projek word deur die Christendom geritualiseer in die liefdesmaal en later in die eucharistie.

'n Twintigste eeuse voorbeeld van soqxqsimboliese optrede metqxqpolitieke strekking is Gandhi se projek van burgerlike ongehoorsaamheid van 1930:qxqstaptog van (aanvanklik) 240 myl word deur hom georganiseer uit protes teen die verbod op die maak van sout. Hierdie fyn georkestreerde media-set wat deur Gandhi as 'n kwasi-pelgrimstog gestileer is, word onderneem saam met noukeurig uitgesoekte ondersteuners en eindig op die strand van Dandi, waar die groep die wet sou verbreek deur sout te maak. Die gebeurtenis het enorme reperkussies, deurdat mense oral oor Indië begin het om onwettig sout te makk, gevolg deur stakings, optogte en ander protesbewegings (60 000 mense is in die afloop van die gebeurtenis in hegtenis geneem). Hierdeur is nuwe lewe geblaas in die populistiese beweging, en Gandhi se invloed op en belang vir die onafhanklikheidsbeweging herbevestig (sien Deliège, 1999:56-58).

In sy bespreking van die ontwikkelings in verband met kos in die moderne tyd, wys Goody (1982:133-153 \& 154-174) dat die band tussen klas en kos reeds in die verhale van Chaucer weerspieël word. Die gebruik van kos gaan altyd saam met die opstel van implisiete of eksplisiete status-reëls wat die habitus van die ete reguleer. So het Edward II van Engeland in 1283qxqproklamasie uitgevaardig teen "the outrageous and excessive multitude of meats and dishes which the great men of the kingdom used in their castles, and by persons of inferior rank imitating their example beyond what their stations required" (aangehaal in Goody 1982:141). As Adorno sê dat kunswerkeqxqonbewuste geskiedskrywing of sysmogram van die sosiale kragte in 'n bepaalde historiese konteks is, dan geld dit beslis ook van die kookkuns (vgl. Adorno, 1972:272-273).

Meesal is die vorm van kosgebruik baie behoudend ${ }^{21}$. Waarskynlik kan hierdie behoudendheid toegeskryf word aan die eksistensiële relevansie van die maaltyd. Kos het egter al in politiekqxqgroter rol gespeel as die modderkoekgooiery tussen politici. Goody merk 'n tendens op van "revolusionêre puritanisme" in Tito se reaksie teen Sta-

20 Tydens die banket ná die inhuldiging van president Mandela is onder andere krokodilvleis geëet. Ek kan nie help om plesier te vind in die gedagte dat hierdie gebaar as 'n rituele eet van die 'Groot Krokodil'" gesien kan word nie.

21 Vgl. Goody (1982:151): 'The 'rituals of family living” are marked by formality and continuity.' 
linistiese weelde, asook in die agenda van Mao Tse-Tung. As reaksionêre strategie, poog dit om die winde van verandering aan te blaas deur neerhalend te wys op die seksuele en gastronomiese jolyt van die haves en dit te kontrasteer met die gebrek en matigheid van die have-nots.

Die sosio-politieke implikasies van kos en die kookkuns word nog veel verder uitgewerk in filosofie, soos allerhande eietydse debatte oor die etiese relevansie van kos bewys. So byvoorbeeld wys Whitehead (1994) op die invloed wat seksistiese waardes op kos-praktyke uitgeoefen het. $^{22}$ In die debat oor genadedood, stel Carson (1986)qxqsaak vir die simboliese waarde (naamlik medelye) daarvan om 'n pasiënt steeds aan te hou voed, selfs al is daar geen hoop op genesing nie. Hoell (1984) is een van die etici wat die verpligting oordink wat die nuwe "global village" op die wêreld lê ten opsigte van die uitwissing van hongersnood.

Hierdie oorwegings toon duidelik hoe die kos en die kookkuns voortdurend na konteks verwys. Die veelvormige simboliese, rituele, seksuele, politieke, ideologiese en etiese verwysings konstitueer ook die habitus van eet en van die gastronomies-estetiese ervaring.

\section{Bibliografie}

Adorno, T.W. 1972. Ästhetische Theorie. Gesammelte Schriften, band 7. Frankfurt-am-Main: Suhrkamp.

Ahmed, R. 1994. The Black Art. London: Senate.

Atkins, R. 1990. Art Speak. A guide to contemporary ideas, movements, and buzzwords. New York: Abbeville.

Brillat-Savarin, A. 1826. La physiologie du goût. Paris. Uitgewer onbekend.

Carson, R.A. 1986. "The symbolic significance of giving to eat and drink". In: Lynn, J. (ed.) By no extraordinary means. The choice to forgo life-sustaining food and water, Indianapolis: Indiana Univerity Press.

Deliège, R. 1999. Gandhi. (Que sais-je? 3501). Paris: P.U.F.

Descartes, R. 1641[1967]. Meditationes de prima philosophia. In: Oeuvres philosophiques, band II (1638-1642). Paris: Garnier.

Goody, J. 1982. Cooking, Cuisine and Class. A study in comparative sociology. Cambridge: Cambridge University Press.

Greschat, H.-J. 1980. "Essen und Trinken: Religions-phänomenologisch". In: Josuttis, M. \& Martin, G.M. Das heilige Essen. Kulturwissenschaftliche Beiträge zum Verständnis des Abendmahls, pp. 29-39. Berlin, Kreuz Verlag.

Hegel, G.W.F. 1835[1970]. Vorlesungen über die Ästhetik, I. Werke in zwanzig Bänden 13, Theroie Werkausgabe. Frankfurt am Main: Suhrkamp.

Hegel, G.W.F. 1979. Hegel's Introduction to Aesthetics. Tr. T.M. Knox. Oxford: Clarendon Press.

Hoell, G. 1984. Global Problem Ernährung. Deut Z Phil 32, pp. 527-536.

22 Hier is 'n heel ironiese geval waar seksisme homself in die voet geskiet het. Die gemarginaliseerde rol wat gastronomiese skoonheid in die estetika ingeneem het, is in die huisgesin gerepliseer deur die kookkuns na die domein van die vrou te skuif. Hierdeur is die man in die alledaagse lewe van gastronomiese kreatiwiteit ontneem. 
Kant, I. 1790[1991]. Kritik der Urteilskraft. Stuttgard: Reclam.

Lyotard, J.-F. 1991. The Inhuman. Reflexions on time. California: Stanford University Press.

Marx, K.1872[1932]. Das Kapital. Kritik der politischen Ökonomie. (volgens 2e uitgawe). Berlin: Gustav Kiepenheuer Verlag.

Messelken, K. 1980. "Vergemeinschaftung durchs Essen”. In: Jouttis, M. \& Martin G.M. Das heilige Essen. Kultur- wissenschaftliche Beiträge zum Verständnis des Abendmahls, pp. 41- 58. Berlin, Kreuz Verlag.

Korsmeyer, C. 1999. Making sense of taste. Food and Philosophy. Cornell University Press: Ithaca \& London.

Kroll, W. \& Mittelhaus, K. (reds.) 1932. "Symposion-Literatur,"in: Paulys Real-Encyclopädie der classischen Altertums-wissenschaft. Band 28. Stuttgart: J.B. Metzersche Verlagsbuchhandlung.

Quinet, M.L. 1981. "Food as Art: The problem of function". Brit J Aes 21, pp. 159-171.

Rousseau, J.-J. 1990 [1755]. Discours sur l'origine et les fondements de l'inégalité parmi les hommes. Paris: Agora.

Telfer, E. 1996. Food for thought. Philosophy and Food. Routledge: London \& New York.

Van Staden, P. 1991. Compassion - the Essence of Life. A socio-scientific study of the religious symbolic universe reflected in the ideology/theology of Luke. HTS Supplementum 4.

Versfeld, M. 1982. Tyd en dae. Essays - uitgesoek en ingelei deur W.A. de Klerk. Kaapstad: Tafelberg.

Versfeld, M. 1985. Pots and poetry. Kaapstad: Tafelberg.

Versfeld, M. 1991a. Food for Thought. A philosopher's Cookbook. Cape Town: The Carrefour Press.

Whitehead, A. 1994. "Food Symbolism, Gender Power and the Family". In: Harris-White, B. \& Hoffenberg, R. (eds.) Food. Multidisciplinary Perspectives, pp. 116-129. Oxford: Blackwell.

Zauner, J. 1980. "Einverleibung und Individuation”. In: Josuttis, M. \& Martin, G.M. Das heilige Essen. Kulturwissenschaftliche Beiträge zum Verständnis des Abendmahls, pp. 83-93. Berlin: Kreuz Verlag. 
Kant, I. 1790[1991]. Kritik der Urteilskraft. Stuttgard: Reclam.

Lyotard, J.-F. 1991. The Inhuman. Reflexions on time. California: Stanford University Press.

Marx, K.1872[1932]. Das Kapital. Kritik der politischen Ökonomie. (volgens 2e uitgawe). Berlin: Gustav Kiepenheuer Verlag.

Messelken, K. 1980. "Vergemeinschaftung durchs Essen”. In: Jouttis, M. \& Martin G.M. Das heilige Essen. Kultur- wissenschaftliche Beiträge zum Verständnis des Abendmahls, pp. 41- 58. Berlin, Kreuz Verlag.

Korsmeyer, C. 1999. Making sense of taste. Food and Philosophy. Cornell University Press: Ithaca \& London.

Kroll, W. \& Mittelhaus, K. (reds.) 1932. "Symposion-Literatur,"in: Paulys Real-Encyclopädie der classischen Altertums-wissenschaft. Band 28. Stuttgart: J.B. Metzersche Verlagsbuchhandlung.

Quinet, M.L. 1981. "Food as Art: The problem of function". Brit J Aes 21, pp. 159-171.

Rousseau, J.-J. 1990 [1755]. Discours sur l'origine et les fondements de l'inégalité parmi les hommes. Paris: Agora.

Telfer, E. 1996. Food for thought. Philosophy and Food. Routledge: London \& New York.

Van Staden, P. 1991. Compassion - the Essence of Life. A socio-scientific study of the religious symbolic universe reflected in the ideology/theology of Luke. HTS Supplementum 4.

Versfeld, M. 1982. Tyd en dae. Essays - uitgesoek en ingelei deur W.A. de Klerk. Kaapstad: Tafelberg.

Versfeld, M. 1985. Pots and poetry. Kaapstad: Tafelberg.

Versfeld, M. 1991a. Food for Thought. A philosopher's Cookbook. Cape Town: The Carrefour Press.

Whitehead, A. 1994. "Food Symbolism, Gender Power and the Family". In: Harris-White, B. \& Hoffenberg, R. (eds.) Food. Multidisciplinary Perspectives, pp. 116-129. Oxford: Blackwell.

Zauner, J. 1980. "Einverleibung und Individuation”. In: Josuttis, M. \& Martin, G.M. Das heilige Essen. Kulturwissenschaftliche Beiträge zum Verständnis des Abendmahls, pp. 83-93. Berlin: Kreuz Verlag. 